\title{
Pengalaman Orang Tua Sebagai Prediktor Pengetahuan, Sikap, Self Efficacy Orang Tua Dalam Edukasi Pencegahan Kekerasan Seksual Pada Anak
}

\author{
Crisdiansyah ${ }^{1}$ Linda Suwarni ${ }^{2}$, Selviana $^{3}$, Vidyastuti ${ }^{4}$, Helfi Nolia $^{5}$ \\ Universitas Muhammadiyah Pontianak ${ }^{1234}$ \\ Poltekes Kemenkes Medan ${ }^{5}$ \\ Email: ${ }^{1}$ crisdiansyah78@gmail.com, ${ }^{2}$ lindasuwarni@unmuhpnk.ac.id, ${ }^{3}$ selviana@unmuhpnk.ac.id, \\ ${ }^{4}$ vidyastuti@unmuhpnk.ac.id, ${ }^{5}$ helfinolia@gmail.com
}

\begin{abstract}
Background: Parental education is important in preventing sexual violence against children. Parents need good knowledge, attitudes, and self-efficacy to educate their children, though their effectiveness is affected by various factors. Objective: This study aimed to predict the knowledge, attitudes, and self-efficacy of parents in education to prevent sexual violence in children. Methods: A quantitative design with a cross-sectional approach was used. The sample is 400 parents who have children aged 12-17 years. Data was collected through direct interviews and analyzed using univariate and bivariate (Chi-Square test with 95\% CI). Results: the experience of parents receiving education on preventing sexual violence against children correlate with knowledge $(\mathrm{p}$-value $=0.012)$, attitude $(\mathrm{p}$-value $=0.0000)$ and self-efficacy $(\mathrm{p}$-value $=0.000)$. Conclusion: The experience of parents helps predict knowledge, attitudes, and self-efficacy in providing education to prevent sexual violence against children.)

Keywords: parental experience, knowledge, attitude, self-efficacy, sexual violence in children
\end{abstract}

\begin{abstract}
ABSTRAK
Belakang: Edukasi pencegahan kekerasan seksual dari orang tua sangat penting dalam pencegahan kekerasan seksual pada anak. Orang tua harus memiliki pengetahuan, sikap dan self efficacy yang baik untuk mampu memberikan edukasi pencegahan kekerasan seksual pada anaknya. Berbagai faktor yang mempengaruhi kemampuan orangtua untuk dapat melakukan edukasi tersebut. Tujuan: untuk memprediksi pengetahuan, sikap, dan self efficacy orang tua dalam edukasi pencegahan kekerasan seksual pada anak. Metode: Jenis penelitian kuantitatif dengan pendekatan cross-sectional. Sampel penelitian adalah 400 orang tua yang memiliki anak usia 12-17 tahun. Pengumpulan data dilakukan melalui wawancara lansung. Analisa data univariat dan bivariat (uji Chi Square dengan 95\% CI). Hasil: pengalaman orang tua mendapatkan edukasi pencegahan kekerasan seksual pada anak berhubungan dengan pengetahuan ( $\mathrm{p}$ value $=0,012$ ), sikap ( $\mathrm{p}$ value $=0,0000$ dan self efficacy ( $\mathrm{p}$ value $=0,000$ ) orang tua. Kesimpulan: Pengalaman orang tua mendapatkan edukasi seksual dapat menjadi prediktor pengetahuan, sikap, dan self efficacy orang tua dalam memberikan edukasi pencegahan kekerasan seksual pada anaknya.
\end{abstract}

Kata kunci: pengalaman orang tua, pengetahuan, sikap, self efficacy, kekerasan seksual anak 


\section{PENDAHULUAN}

\section{Latar Belakang (Opsional)}

Kasus child sexual abuse (CSA) atau pelecehan seksual anak di Indonesia masih cukup tinggi. Komisi Perlindungan Anak Indonesia (KPAI) mencatat ada 458 aduan kasus CSA di tahun 2018. Pada Januari 2019 hingga Mei 2019 tercatat 236 kasus CSA yang dilaporkan. Angka tersebut hanya berdasarkan pengaduan, belum menggambarkan kasus CSA yang terjadi sebenarnya (KPAI, 2019). Berdasarkan Data Sistem Informasi Online Perlindungan Perempuan dan Anak (2020) pada periode 1 Januari - 31 Juli 2020 jumlah anak korban kekerasan seksual mencapai 2.556 anak dari total 4.116 kasus. Jumlah kasus terus mengalami penambahan pada bulan Agustus mencapai 4.833 kasus. Menurut Kementerian Perlindungan Perempuan dan Anak (Kemen PPA), dua dari tiga anak di Indonesia pernah mengalami tindak kekerasan baik secara verbal maupun nonverbal.

Pengetahuan orang tua yang kurang terhadap seks membuat pendidikan seksual dalam keluarga di kurang. Sehingga, informasi diperolehremaja dari teman, majalah dan internet (Hasfah, 2021) . Banyak orang tua yang kurang peduli dan merasa risih untuk membicarakan masalah seksual kepada anaknya. Namun, seksualitas merupakan hal yang tabu untuk dibicarakan dalam keluarga Indonesia, padahal mengawali pemberian pendidikan seksualitas pada anak, akan menolong untuk memahami tubuhnya (Opara, 2010).

Pengalaman seksual yang kurang tepat juga dapat membuat anak memiliki persepsi yang salah terkait alat dan proses reproduksi, serta seksualitasnya. Jika dibiarkan, hal tersebut dapat menyebabkan anak mengalami kekeliruan perilaku seks dikemudian hari (Trinita, 2017). Disamping itu, anak juga memiliki rasa keingintahuan yang tinggi. Apabila anak tidak menemukan jawaban atas rasa ingin tahunya, mereka cenderung akan mencari informasi melalui teman sebaya maupun sumber lain. Informasi tersebut belum tentu benar dan bisa saja menyesatkan (Ratnasari, 2016).

Kekerasan seksual seringkali terjadi tanpa di ketahui oleh orang tua. Anak biasanya akan takut melaporkan apa yang dialaminya. Ancaman bujukan dan rasa iba mungkin digunakan pelaku untuk memikat anak, atau menghambat anak agar tidak bercerita kepada orang tua (Handayani, 2017). Anak yang menjadi korban bisa jadi tidak tahu bahwa apa yang dialaminya adalah kekerasan seksual. Sebuah penelitian menyebutkan bahwa kasus kekerasan yang terjadi tidak terlepas dari minimnya pengetahuan korban yang masih berusian kanak-kanak dan kurangnya bimbingan orang tua tentang keamanan untuk menjaga wilayah pribadi (maslihah, 2013).

Dampak pada kesehatan yaitu trauma yang berkepanjangan. Pengalaman orang tua tentang seksual yang kurang tepat juga dapat membuat anak memiliki persepsi yang salah terhadap alat, proses reproduksi, dan seksualitasnya. Jika diabaikan, dapat menyebabkan anak keliru terhadap perilaku seks dikemudian hari. Maka dari itu anak juga memiliki rasa keingintahuan yang tinggi. Jika anak tidak menemukan jawaban atas rasa ingn tahu, mereka akan mencari informasi ke sumber lain yang mana informasi tersebut belum tentu benar dan bisa menyesatkan. Sebagai orang tua bertanggung jawab dalam hal ini karena orang tua sebagai guru pertama yang berkontribusi dalam mendidik, mengasuh dan membentuk watak seorang anak.

Penelitian ini bertujuan untuk memprediksi pengetahuan, sikap, serta self efficacy para orang tua dalam memberikan pendidikan seksual terhadap anak mereka sebagai upaya pencegahan kekerasan seksual.

\section{METODE}

Penelitian ini merupakan penelitian deskriptif kuantitatif dengan menggunakan pendekatan potong-lintang (Cross-Sectional). Populasi dalam penelitian ini adalah seluruh orang tua yang mempuyai anak 12-17 tahun di Kota Pontianak. Sampel dalam penelitian ini sebanyak 400 orang tua. Teknik pemilihan sampel dengan consecutive sampling yang dilakukan di 6 kecamatan di Kota Pontianak. Pengumpulan data dilakukan pada bulan Juni 2021 melalui wawancara lansung dengan menerapkan protokol Kesehatan.

Kuesioner terdiri dari empat bagian utama yaitu pengalaman orang tua mendapatkan edukasi mengnenai seksual, pengetahuan orang tua, sikap orang tua, dan self efficacy (efikasi diri) para orang tua dalam pemberian edukasi pencegahan seksual pada anaknya. Analisis data yang digunakan adalah analisis Univariat dan Bivariat. Untuk mengetahui hubungan variabel bebas dan variabel terikat menggunakan uji Chi Square. Penelitian ini sudah mendapatkan Etikal Clereance dari Komisi Etik Penelitiah Kesehatan Fakultas Ilmu Kesehatan Universitas Negeri Semarang.

\section{HASIL}

\section{Karakteristik Responden}

Gambaran karakteristik responden dan hasil analisis univariat dapat dilihat pada table di bawah ini 
Tabel 1. Karakteristik Responden

\begin{tabular}{lcc}
\hline \multicolumn{1}{c}{ Variabel } & Frekuensi & $\begin{array}{c}\text { Persentase } \\
(\mathbf{\%})\end{array}$ \\
\hline Jenis kelamin & & \\
Laki-Laki & 82 & 20.5 \\
Perempuan & 318 & 79.5 \\
\hline Status Pernikahan & & \\
Menikah & 368 & 92.0 \\
Duda/Janda & 32 & 8.0 \\
\hline Pekerjaan & & \\
PNS & 42 & 10.5 \\
Wiraswasta & 349 & 87.25 \\
Polri & 1 & 0.25 \\
TNI AD & 2 & 0.50 \\
Pensiuanan & 6 & 1.50 \\
\hline Pendidikan & & \\
Tamat SD & 70 & 17.5 \\
Tamat SMP & 86 & 21.5 \\
Tamat SMA & 178 & 44.5 \\
Perguruan & 66 & 16.5 \\
Tinggi & & \\
\hline Total & 400 & 100.0 \\
\hline
\end{tabular}

Tabel 1 di atas menunjukan bahwa proporsi responden terbesar jenis kelamin perempuan (79.5\%), status pernikahan menikah (92\%), bekerja sebagai wiraswasta $(87.25 \%)$, berpendidiakn tamat SMA (44.5\%) menurut jawaban responden

Hasil Analisis Univariat

Berikut ini hasil analisa univariat:

Tabel 2. Hasil Analisis Univariat

\begin{tabular}{|c|c|c|}
\hline Variabel & Frekuensi & $\begin{array}{c}\text { Persentase } \\
(\%)\end{array}$ \\
\hline \multicolumn{3}{|c|}{ Pernah menyampaikan edukasi } \\
\hline Tidak pernah & 237 & 59.3 \\
\hline Pernah & 163 & 40.8 \\
\hline \multicolumn{3}{|c|}{ Pengetahuan orang tua } \\
\hline Kurang baik & 225 & 56.3 \\
\hline Baik & 175 & 43.8 \\
\hline \multicolumn{3}{|c|}{ Sikap orang tua } \\
\hline Negative & 207 & 51.7 \\
\hline Positif & 193 & 48.3 \\
\hline \multicolumn{3}{|l|}{ Self efficacy } \\
\hline Rendah & 201 & 50.2 \\
\hline Tinggi & 199 & 49.8 \\
\hline Total & 400 & 100.0 \\
\hline
\end{tabular}

Sumber: Data Primer 2021

Tabel 2 hasil analisa univariate yaitu, sebagian besar responden tidak pernah memyampaikan edukasi kepada anak (59.3\%), tingkat pengetahuan orang tua kurang baik $(56.3 \%)$, sikap negative orang tua
(51.7\%), dan self efficacy rendah (50.2\%) dalam memberikan edukasi pencegahan kekerasan seksual pada anak.

\section{Hasil Analisis Bivariat}

Berdasarkan tabel 3 hasil analisis bivariat dengan menggunakan uji Chi-square menunjukkan bahwa pengalaman orang tua mendapatkan edukasi pencegahan kekerasan seksual berhubungan dengan pengetahuan $(\mathrm{P}$ value $=0,012 ; \mathrm{PR}=1.271)$ dan sikap ( $p$ value $=0,000 ; 1.502)$, serta self efficacy $(\mathrm{p}$ value $=$ 0,$000 ; 1.781$ ) orang tua tentang pemberian edukasi pencegahan seksual pada anak. Tabel tersebut juga menunjukkan bahwa orang tua yang tidak pernah mendapatkan pengalaman edukasi seksual memiliki peluang pengetahuan yang rendah mengenai pencegahan edukasi kekerasan seksual pada anak sebesar 1,271 kali, memiliki peluang sikap yang negatif mengenai edukasi pencegahan kekerasan seksual pada anak sebesar 1,502 kali, serta memiliki peluang self efficacy yang rendah mengenai edukasi pencegahan kekerasan seksual pada anak sebesar 1,781 kali.

\section{Table 3. Analisis bivariate}

Tabel 3 di bawah ini menunjukkan hasil analisa bivariate yang menggunakan uji Chi Square dengan 95\% CI. Berikut hasil analisis tersebut : 
Vol. 10 No. 1 Januari - April 2019

\begin{tabular}{|c|c|c|c|c|c|c|c|}
\hline \multirow{4}{*}{$\begin{array}{l}\text { Pengalaman Orang Tua } \\
\text { Mendapatkan Edukasi } \\
\text { Seksual }\end{array}$} & \multicolumn{4}{|c|}{ Pengetahuan } & \multirow[t]{4}{*}{$P$ value } & \multirow[t]{4}{*}{$\mathbf{P R}$} & \multirow[t]{4}{*}{ CI $95 \%$} \\
\hline & \multicolumn{2}{|c|}{ Kurang Baik } & \multicolumn{2}{|c|}{ Baik } & & & \\
\hline & & $\%$ & $\mathrm{~N}$ & $\%$ & & & \\
\hline & & & & & & & \\
\hline Tidak Pernah & 146 & 61,6 & 91 & 38,4 & 0,012 & 1,271 & $1,054-1,533$ \\
\hline \multirow[t]{2}{*}{ Pernah } & 79 & 48,5 & 84 & 51,5 & & & \\
\hline & \multicolumn{4}{|c|}{ Sikap } & P value & PR & CI $95 \%$ \\
\hline Pengalaman Orang Tua & \multicolumn{2}{|c|}{ Negatif } & \multicolumn{2}{|c|}{ Negatif } & & & \\
\hline Mendapatkan Edukasi & $\mathrm{n}$ & $\%$ & $\mathrm{~N}$ & $\%$ & & & \\
\hline Tidak Pernah & 142 & 59,9 & 95 & 40,1 & 0,000 & 1,502 & $1.211-1.864$ \\
\hline Pernah & 65 & 39,9 & 98 & 60,1 & & & \\
\hline \multirow{3}{*}{$\begin{array}{l}\text { Pengalaman Orang Tua } \\
\text { Mendapatkan Edukasi } \\
\text { Seksual }\end{array}$} & \multicolumn{4}{|c|}{ Sel Efficacy } & P value & PR & CI $95 \%$ \\
\hline & \multicolumn{2}{|c|}{ Rendah } & \multicolumn{2}{|c|}{ Tinggi } & & & \\
\hline & $\mathrm{n}$ & $\%$ & $\mathrm{~N}$ & $\%$ & & & \\
\hline Tidak Pernah & 145 & 61,2 & 92 & 38,8 & 0,000 & 1,781 & $1.408-2.253$ \\
\hline Pernah & 56 & 34,4 & 107 & 65,5 & & & \\
\hline
\end{tabular}

\section{PEMBAHASAN}

Penelitian ini menemukan bahwa orang tua yang belum pernah mendapatkan edukasi seksual pada anak berpengaruh pada pengetahuan, sikap, dan self efficacy mereka dalam memberikan edukasi pencegahan kekerasan seksual pada anak. sepenuhnya menyampaikan edukasi kepada anak tentang seksual. Hal ini terbukti dengan $59.3 \%$ orang tua belum pernah mendapatkan edukasi

pencegahan kekerasan seksual. Banyak orang tua yang masih menganggap hal ini tabu sehingga orang tua menjadi bingung cara memberikan edukasi pencegahan kekerasan seksual pada anak mereka. Hal ini berakibat edukasi yang mesti dilakukan orang tua mengenai penegahan kekerasan seksual kepada anak tidak dilakukan dengan baik, dan membiarkan anak untuk mendapatkan pengetahuan tersebut dari luar. Pembahasan kekerasan seksual hanya menjadi pembicaraan sepintas saja. Padahal orang tua berpotensi mengembangkan kemampuan dalam melindungi anaknya dari kekerasan seksual apabila orang tua memiliki informasi yang cukup terkait pravelensi kasus kekerasan seksual pada anak, keseriusan terhadap kasus tersebut dan strategi pencegahannya (Glanz, 2008).

Sebagian besar orang tua menganggap pendidikan seksual sebagai sesuatu yang tidak penting diajari ke anak karena anak akan tahu dengan sendirinya seiring dengan perkembangan usianya. Salah satu faktor yang mempengaruhi pencegahan kekerasan seksual pada anak adalah pengetahuan orang tua yang masih rendah dengan anggapan bahwa mengiformasikan tentang seksualitas akan berdampak negatif pada anak. Hal ini sejalan dengan penelitian sebelumnya bahwa orang tua tidak memberi pendidikan seksual pada anak karena kurang pengetahuan dalam memberikan pendidikan seksual sesuai usia anak (Ligina, 2018). Padahal pendidikan seksual tidak selalu tentang hubungan seksual, namun informasi mengenai pendidikan seksual yang didapat oleh orang tua sangat sedikit untuk bisa memberi pendidikan seksual pada anak (Isni, 2017) (Wibisono, 2017).

Faktor lain yang berpengaruh dari pengalaman (pernah atau tidaknya) orang tua mendapatkan edukasi pencegahan seksual adalah sikap orang tua. Orang tua yang tidak memiliki pengalaman mendapatkan edukasi pencegahan kekerasan seksual akan mempengaruhi sikapnya dalam memberikan edukasi seksual kepada anaknya. Sehingga sikap yang negative dan cenderung membiarkan anaknya untuk mencari sendiri informasi mengenai seksual membuat orang tua bersikap individualistis kurang dalam kontrol dan pengertian terhadap anak (Anugraheni, 2012). Hal tersebut menyebabkan sikap orang tua rendah kesadarannya dalam memberikan edukasi pada anak (Awaru, 2020). Hal ini mengakibatkan orang tua cenderung untuk tidak memberikan pendidikan seks untuk anaknya, sehingga menyebabkan anak semakin tidak terbuka untuk menceritakan tentang kesehatan reproduksi ke orang tua (Chasanah, 2018) (Wibisono et al., 2017). 
Selain sikap orang tua, faktor lain yang berpengaruh dari pengalaman orang tua mendapatkan edukasi pencegahan seksual adalah yaitu self efficacy. Efikasi diri (self efficacy) adalah keyakinan diri seseorang dalam berperilaku yang dapat mempengaruhi variabel lain seperti perilaku (Wentzel, 2016). Sebagaimana temuan dalam penelitian ini menunjukkan bahwa orang tua yang tidak memiliki pengalaman mendapatkan edukasi pencegahan kekerasan seksual berpeluang 1,271 kali memiliki self efficacy/keyakinan diri yang rendah untuk memberikan edukasi kekerasan seksual pada anak. Padahal self efficacy ini sangat penting dalam mempengaruhi kemampuan orang tua dalam memberikan edukasi pencegahan kekerasan seksual pada anak (Hakim, 2017). Efikasi diri yang rendah dapat membuat orang tua tidak bisa mengedukasi anaknya (Abdullah, 2019).

Saat orang tua mau membicarakan seksualitas pada anak, hal ini akan membuat orang tua memiliki otoritas penuh pada anak sehingga mereka akan selalu menjadi rujukan bagi anak (Wilson, 2010). Orang tua seharusnya memberikan pendamping penuh terhadap batasan perilaku seksual (Wanufika, 2017).

Hal ini seharusnya lebih mendorong orang tua untuk memberikan bekal perlindungan diri pada anak. Perlindungan diri yang dimaksud tidak hanya tentang olahraga bela diri, namun juga pengenalan terhadap perilaku yang melewati batas area pribadi pada tubuhnya atau potensi pelecehan seksual (Asampong, 2013). Orang tua harus mulai mengajari anak tentang tubuhnya dan batas area pribadi yang boleh disentuh atau tidak dan orang-orang yang boleh menyentuhnya (Walsh K, 2012) (Kenny, 2010).

\section{KESIMPULAN}

Hasil penelitian ini di simpulkan bahwa pengalaman orang tua mendapatkan edukasi pencegahan kekerasan seksual berhubungan dengan pengetahuan, sikap, dan self efficacy orang tua. sehingga pengalaman orang tua mendapatkan edukasi seksual dapat menjadi prediktor pengetahuan, sikap, dan self efficacy orang tua dalam memberikan edukasi pencegahan kekerasan seksual pada anaknya.

\section{DAFTAR PUSTAKA}

1. Abdullah, S. M. (2019). Social Cognitive Theory: A Bandura Thought Review published in 1982-2012. Psikodimensia, 18(1), 85. https://doi.org/10.24167/psidim.v18i1.170 8
2. Anugraheni, E., Mahasiswa, E. A., Km, N. L. S., Dpu, M. K. E. S., Rokhmah, D., Kesehatan, P., Masyarakat, K., Unej, U. J., \& Kalimantan, J. (2012). Hubungan Pengetahuan dan Sikap Orang Tua Tentang Pendidikan Seks dengan Tindakan Orang tua dalam pemberian Pendidikan Seks pada Remaja ( Studi di Kecamatan Sumbersari Kabupaten Jember )( The Relation between knowledges and attitudes of parents about sex .

3. Asampong E, Osafo J, B. J., \& C., A. (2013). Adolescents and parents' perceptions of best time for sex and sexual communications from two communities in the Eastern and Volta Regions of Ghana: implications for HIV and AIDS education. $B M C$ international health and human rights. 2013. Dec;13(1):40. https://doi.org/10.1186/1472-698X-13-40

4. Awaru, A. O. T. (2020). Konstruksi Sosial Pendidikan Seksual pada Orangtua dalam Keluarga Bugis-Makassar. 8(1), 182-199.

5. Chasanah, I. (2018). Psikoedukasi Pendidikan Seks untuk Meningkatkan Sikap Orangtua dalam Pemberian Pendidikan Seks. Jurnal Intervensi Psikologi (JIP), 10(2), 133-150. https://doi.org/10.20885/intervensipsikolo gi.vol10.iss2.art5

6. Glanz, K, Rimer, BK, Viswanath, K. (2008). Health Behaviour and Health Education. San Fransisco : Jossey-Bass.

7. Hakim, N., \& Anugrahwati, R. (2017). Efektivitas Komik Terhadap Self Efficacy Upaya Pencegahan Kekerasan Pada Anak Usia Sekolah. Care: Jurnal Ilmiah Ilmu Kesehatan, $5(3), \quad 359$. https://doi.org/10.33366/cr.v5i3.704

8. Handayani, M. (2017). Pencegahan Kasus Kekerasan Seksual Pada Anak Melalui Komunikasi Antarpribadi Orang Tua Dan Anak. JIV-Jurnal Ilmiah Visi, 12(1), 6780. https://doi.org/10.21009/jiv.1201.7

9. Hasfah, Wardani D, G. K. (2021). Literature Review: Intervensi Kebidanan Terkini Peningkatan Sikap Orang Tua dalam Memberikan Pendidikan Seksual Pada Anak untuk Pencegahan Child Sexual 


\section{Vol. 10 No. 1 Januar i - April 2019}

10. Abuse. Journal of Issues in Midwifery, 5(2), $87-100$.

https://doi.org/10.21776/ub.joim.2021.005. 02.5

11. Isni, K., \& Handayani, L. (2017). Needs Assesment of Adolescent Health Services. International Journal of Public Health Science (IJPHS), $\quad 6(1), \quad 72$. https://doi.org/10.11591/ijphs.v6i1.6535

12. Kenny MC, W. S. (2010). Children's abilities to recognize a "good" person as a potential perpetrator of childhood sexual abuse. 1;34(7):490-5. https://doi.org/10.1016/j.chiabu.2009.11.00 7

13. KPAI. (2019). Jumlah Kasus Anak Korban Pelecehan Seksual.

14. Ligina, N.L., D. (2018). Peran orang tua dalam pencegahan kekerasan seksual pada anak sekolah dasar di Kota Bandung. Ejournal UMM, 9(2), 109-118. http://ejournal.umm.ac.id/index.php/kepera watan/article/view/5454\%0A

15. Opara, P. I., Eke, G. K., \& Akani, N. A. (2010). Mothers perception of sexuality education for children. Nigerian Journal of Medicine: Journal of the National Association of Resident Doctors of Nigeria, 19(2), 168-172. https://doi.org/10.4314/njm.v19i2.56513

16. Ratnasari, R. F., \& Alias, M. (2016). Pentingnya Pendidikan Seks untuk Anak Usia Dini. Jurnal Tarbawi Khatulistiwa, 2(2), 55-59.

17. SIMFONI, P. (2020). Data Sistem Informasi Online Perlindungan Perempuan dan Anak. https://kekerasan.kemenpppa.go.id/

18. Trinita, A. (2017). PENDIDIKAN SEKS UNTUK ANAK USIA 4-5 TAHUN DI PAUD IT QURROTA A YUN KOTA BANDAR LAMPUNG.

19. Walsh K, B. L. (2012). Their children's first educators: Parents' views about child sexual abuse prevention education. Journal of Child and Family Studies. Oct 1;21(5):734-46.

https://doi.org/https://doi.org/10.1007/s108 26-011-9526-4
20. Wanufika, I., Sumarni, S., \& Ismail, D. (2017). Komunikasi orang tua tentang seksualitas terhadap perilaku seksual pranikah pada remaja (Parental communication about sexuality on premarital sexual behaviorin adolescents). Berita Kedokteran Masyarakat, 33(10), 495-500.

21. Wentzel, K. R., Miele, D. B., Schunk, D. H., \& Dibenedetto, M. K. (2016). Self-Efficacy Theory in Education. Handbook of Motivation at School. https://doi.org/10.4324/9781315773384

22. Wibisono, Z. N., Yuliadi, I., \& Suwito, D. (2017). Hubungan Tingkat Pendidikan Orang Tua dan Status Ekonomi dengan Perilaku Seksual Remaja Di SMA Negeri 2 Surakarta. Nexus Kedokteran Komunitas, 6(2), 92-100.

23. Wilson, E. K., Dalberth, B. T., Koo, H. P., \& Gard, J. C. (2010). Parents' Perspectives on Talking to Preteenage Children About Sex. Perspectives on Sexual and Reproductive Health, 42(1), 56-63. https://doi.org/10.1363/4205610 